\title{
SLFN11 Gene
}

National Cancer Institute

\section{Source}

National Cancer Institute. SLFN11 Gene. NCI Thesaurus. Code C116956.

This gene plays a role in anti-viral defense. 